\title{
ОСОБЛИВОСТІ ВУГЛЕВОДНОГО ТА ЛІПІДНОГО ОБМІНУ В ЖІНОК ПРЕМЕНОПАУЗАЛЬНОГО ВІКУ 3 ГІПОТИРЕОЗОМ АВТОІМУННОГО ГЕНЕЗУ
}

Вступ. Дисфункцію щитоподібної залози вважають поширеним ендокринним захворюванням, у структурі якого переважає гіпотиреоз. У більшості випадків гіпотиреоз є наслідком автоімунного тиреоїдиту, що найчастіше трапляється в жінок. Зростання рівня тиреотропного гормону корелює з параметрами метаболічного синдрому, що збільшує серцево-судинні події та загальну смертність.

Мета дослідження - вивчити особливості кореляційних взаємозв'язків тиреотропного гормону, тиреоїдних гормонів та антитіл до тиреопероксидази з вуглеводно-ліпідними показниками в жінок пременопаузального віку, хворих на гіпотиреоз автоімунного генезу.

Методи дослідження. Обстежено 146 жінок пременопаузального віку з гіпотиреозом автоімунного генезу. Всім пацієнткам проводили антропометричні, загальноклінічні, біохімічні обстеження, включаючи визначення вуглеводного та ліпідного обміну, оцінювали ффункціональний стан їх щитоподібної залози, визначаючи рівні тиреотропного гормону, вільного тироксину, вільного трийодтироніну та антитіл до тиреопероксидази. Результати досліджень аналізували методом варіаційної статистики за допомогою програми STATISTICA 12 ("Statsoft", СШA).

Результати й обговорення. Рівні тиреотропного гормону та антитіл до тиреопероксидази характеризувалися прямим кореляційним взаємозв'язком середньої сили із загальним холестерином, тригліцеридами, ліпопротеїнами низької щільності, коефіцієнтом атерогенності, а рівні вільного тироксину $і$ вільного трийодтироніну - зворотним зв'язком. Встановлено достовірно позитивні кореляції середньої сили індексу маси тіла й індексу інсулінорезистентності HOMA-IR з тиреотропним гормоном, антитілами до тиреопероксидази та негативні кореляції середньої сили з вільним тироксином і вільним трийодтироніном. Виявлено позитивний кореляційний взаємозв'язок індексу маси тіла та індексу інсулінорезистентності HOMA-IR з рівнями загального холестерину, холестерину ліпопротеїнів низької щільності, тригліцеридів, коефріцієнтом атерогенності й негативний кореляційний взаємозв'язок з холестерином ліпопротеїнів високої щільності.

Висновок. Дослідження кореляційних взаємозв'язків вуглеводного та ліпідного обміну в жінок пременопаузального віку, хворих на гіпотиреоз автоімунного генезу, є актуальним і перспективним напрямком для вивчення механізмів розвитку метаболічного синдрому та його корекції. Замісна гормональна терапія левотироксином натрію в жінок з гіпотиреозом автоімунного генезу є недостатньою для досягнення цільових рівнів основних показників метаболічного обміну.

КЛЮЧОВІ СЛОВА: автоімунний тиреоїдит; гіпотиреоз; жінки; пременопаузальний вік; кореляції; дисліпідемія; інсулінорезистентність.

ВСТУП. У структурі ендокринної патології перше місце посідають захворювання щитоподібної залози (ЩЗ). За даними епідеміологічних досліджень, в окремих групах населення поширеність усіх форм гіпотиреозу (ГТ) сягає 10-12\% [1]. Первинний маніфестний ГТ трапляється найчастіше і становить від 1,4 до 12 \% випадків у популяції, первинний субклінічний - від 7 до $10 \%$ серед жінок і від 2 до $3 \%$ серед чоловіків [2], у більшості випадків ГТ є наслідком автоімунного тиреоїдиту (AIT).

(c) О. О. Чукур, 2020.
Тиреоїдні гормони відіграють важливу роль у вуглеводному та ліпідному обміні, зокрема в регуляції загального обміну, метаболізмі глюкози й окисненні ліпідів [3]. В останні роки доведено їх регулювальний вплив на метаболізм гормонів жирової тканини [4]. Дисффункція адипоцитів, інсулінорезистентність, дисліпідемія пов'язані 3 підвищеним ризиком розвитку метаболічного синдрому (MC) та серцево-судинних захворювань [5]. Останні дослідження показують, що зростання рівня тиреотропного гормону (ТТГ) суттєво корелює з параметрами цього синдрому 
[6], резистентністю до інсуліну та ожирінням [7]. Метаболічний синдром тісно пов'язаний із кардіоваскулярним ризиком, збільшує серцево-судинні події та загальну смертність. Однак залишається дискутабельним питання щодо первинності або вторинності МС при автоімунній патології щ3 [8].

3 огляду на багатофакторність розвитку, значну поширеність ГТ в Україні та відсутність чітких рекомендацій стосовно ефективних заходів профрілактики, необхідно більш детально дослідити фрактори ризику виникнення цієї патології.

Мета дослідження - вивчити особливості кореляційних взаємозв'язків тиреотропного гормону, тиреоїдних гормонів та антитіл до тиреопероксидази з вуглеводно-ліпідними показниками в жінок пременопаузального віку, хворих на гіпотиреоз автоімунного генезу.

МЕТОДИ ДОСЛІДЖЕННЯ. Обстежено 146 жінок з гіпотиреозом на тлі автоімунного тиреоїдиту. В дослідження було включено пацієнток пременопаузального віку (від 40 до 54 років), середній вік становив $(43,8 \pm 0,7)$ року, статус менопаузи визначали за допомогою самозвітної анкети про менструальні кровотечі та їх регулярність. Тривалість захворювання становила $(6,4 \pm 1,7)$ (від 3 до 8) року. Обстежувані перебували на амбулаторному і стаціонарному лікуванні у відділенні ендокринології та ендокринологічному диспансері Університетської лікарні м. Тернополя. 3 дослідження виключали жінок із супутніми хронічними соматичними захворюваннями з тяжким чи прогресуючим перебігом. Усі пацієнтки підписали інорормовану згоду на участь у дослідженні. Після отримання висновку етичної комісії при Тернопільському національному медичному університеті імені І. Я. Горбачевського МОЗ України дослідження проводили, дотримуючись усіх морально-етичних принципів, відповідно до Гельсінської декларації Всесвітньої медичної асоціації з біомедичних досліджень (World Medical Association Declaration of Helsinki).

3 метою встановлення або підтвердження діагнозу здійснювали загальноклінічний огляд, використовували лабораторні та інструментальні методи дослідження. В усіх обстежуваних вимірювали антропометричні показники і вираховували індекс маси тіла згідно з формулою (мaса $(к г) /$ picт $^{2}\left(\mathrm{M}^{2}\right)$ ).

Для оцінки функціонального стану щЗ визначали рівні ТТГ, вільного тироксину $\left(\mathrm{BT}_{4}\right)$ та вільного трийодтироніну $\left(\mathrm{BT}_{3}\right)$ в сироватці крові за допомогою електрохемілюмінесцентного методу на автоматичному аналізаторі Roche
"Cobas-411" з використанням реактивів компанії "Roche Diagnostics" (Німеччина). Рівні антитіл до тиреопероксидази (АТПО) та антитіл до тиреоглобуліну (АТТГ) визначали за допомогою набоpів "Orgentec GmbH" (Німеччина). Діагноз автоімунного тиреоїдиту встановлювали при підвищенні показників АТПО та/або АТТГ і наявності характерної ультрасонографрічної картини щЗ.

3 метою оцінки ліпідного обміну визначали рівні загального холестерину (ЗХС), холестерину ліпопротеїнів високої щільності (ХС ЛПВщ) і тригліцеридів (ТГ) у сироватці крові на автоматичному біохімічному аналізаторі Roche "Cobas-501" з використанням реактивів компанії "Roche Diagnostics" (Німеччина). За показниками ліпідограми визначали: холестерин ліпопротеїнів низької щільності (ХС ЛПНЩ = 3ХС - (ТГ / 2,2 + ХС лПВЩ)) та коефіцієнт атерогенності (КА = (

Для дослідження вуглеводного обміну визначали рівень базальної глюкози в сироватці крові глюкозооксидазним методом на автоматичному біохімічному аналізаторі Roche "Cobas-501" та рівень базального інсуліну в крові електрохемілюмінесцентним методом з використанням автоматичного аналізатора Roche "Cobas-411" і тест-систем компанії "Roche Diagnostics" (Німеччина). Вираховували індекс інсулінорезистентності HOMA-IR (Homeostasis Model Assessment for Insulin Resistance) за формулою: HOMA-IR = (глюкоза натще $\times$ базальний інсулін) : 22,5. У дослідження не було включено хворих на цукровий діабет, оскільки вони отримували цукрознижувальну терапію, яка могла впливати на показник інсулінорезистентності.

Статистичну обробку результатів та візуалізацію отриманих даних здійснювали із застосуванням пакета програми для статистичного аналізу STATISTICA 12. Для оцінки ступеня взаємозв'язку проводили кореляційний аналіз із розрахунком лінійного коефріцієнта кореляції (r) та його достовірності (р). Метод Пірсона визнають найбільш точним щодо вивчення кореляції, оскільки одночасно отримуємо інфрормацію про напрямок взаємодії (пряма +, зворотна -) та силу взаємозв'язку (від 0 до 1). Якщо $r=0$, вважають, що зв'язок відсутній, проміжок 0-0,3 вказує на слабку кореляцію, інтервал 0,3-0,7 свідчить про асоціацію середньої сили, а відрізок від 0,7 до 1,0-про сильний зв'язок. Значимість відмінностей між величинами вважали достовірними при $p<0,05$.

РЕЗУЛЬТАТИ Й ОБГОВОРЕННЯ. ДіаГНОЗ ГТ ґрунтувався на характерних клінічних симптомах і результатах лабораторно-інструментального дослідження. Ми оцінювали функціональний 
стан щЗ у жінок, хворих на ГТ автоімунного генезу, середній рівень ТТГ у них становив $(4,44 \pm 0,21)$ мМо/мл; в $T_{3}-(1,97 \pm 0,09)$ нмоль/л; в $_{4}-(12,96 \pm 0,37)$ нмоль/л; АТПО $(112,87 \pm 5,61)$ Мо/мл; АТТГ - $(152,25 \pm 5,04)$ Мо/мл (p<0,05). Для компенсації ГТ хворі отримували левотироксин натрію в замісних дозах, які становили від 50 до 150 мкг. Відповідно до рівня ТТГ, компенсований ГТ виявлено у 94 жінок (64,4 \%), субкомпенсований - у 52 (35,6 \%). Індекс маси тіла в середньому дорівнював 29,4ะ0,29 у 49,3 \% обстежуваних, що свідчило про надмірну масу тіла, в 65 жінок (44,5 \%) спостерігали ожиріння.

Гіперхолестеринемію понад 5,2 ммоль/л відзначали в 54 жінок (26,8 \%) , рівень ХС ЛПВЩ $<1,15$ ммоль/л - у 69 (48,3\%), ХС лПнщ $>2,6$ ммоль/л - у 76 (75,6 \%), КА >3 - в $64 \%$. Після проведення кореляційного аналізу даних гормонального статусу і ліпідного профрілю було виявлено більшість слабких кореляційних взаємозв'язків та декілька - середньої сили (табл. 1). Позитивні кореляції середньої сили встановлено між рівнями ТТГ і 3ХC $(r=0,45)$, ХС лПнЩ $(r=0,40)$, КА $(r=0,36)$, слабкої сили - 3 ТГ $(r=0,13)$, негативну кореляцію слабкої сили спостерігали 3 ХС ЛПВЩ $(r=-0,14)(p<0,05)$. Натомість в ${ }_{4}$ виявляв протилежну динаміку, оскільки асоціювався у зворотному напрямку із 3XC (r=-0,31), XС ЛПНЩ $(r=-0,27)$, KA $(r=-0,18)(p<0,05)$ та без вірогідних змін - із ХС ЛПВЩ і ТГ. Вільний трийодтиронін також негативно корелював із 3ХС $(r=-0,28)$, ХС лПНЩ $(r=-0,26)$, KA $(r=-0,20)$, і не спостерігали інших достовірних взаємозв'язків $(p<0,05)$.

Після проведення кореляційного аналізу в обстежуваних визначено позитивні взаємозв'язки середньої сили між рівнями АТПО та ЗХС $(r=0,67)$, КА $(r=0,60)$, ХС ЛПНЩ $(r=0,58)$, ТГ $(r=0,48)$, спостерігали негативну кореляцію слабкої сили з ХС лПВщ $(r=-0,34)(p<0,05)$. Відмічали позитивну кореляцію середньої сили між рівнями АТТГ та ХС лПВЩ $(r=0,41)$, КА $(r=0,40)$, $X C$ ЛПНЩ $(r=0,39)$,$) ЗХC (r=0,30), слабкої сили -$ 3 ТГ $(r=0,26)(p<0,05)$.
Результати наших досліджень свідчать про те, що в жінок пременопаузального віку, хворих на гіпотиреоз автоімунного генезу, вміст ТТГ та АТПО і АТТГ корелював позитивно, а в ${ }_{4}$ та в $_{3}-$ негативно 3 показниками ЗХС, ХС ЛПНЩ і КА. Ці результати збігаються з даними інших дослідників, які зафріксували таку ж картину змін (вміст ТТГ асоціювався 3 підвищенням рівнів 3ХС, ХС ПНЩ, ТГ, зниженням вмісту ХС ЛПВЩ) навіть у тих хворих, в яких ТТГ перебував у межах реорерентних значень [9]. Група вчених під керівництвом Luís Raposo (2019) заявила, що в рамках їх дослідження не було відмічено кореляції між ТТГ, вТ 4 та МС, проте спостерігали позитивну кореляцію між $\mathrm{BT}_{3}$ і МC, а також рівнями ТГ та інсуліну, що посилює ймовірну роль $\mathrm{BT}_{3}$ у кардіоваскулярному ризику [10].

Вивчаючи взаємозв'язки індексу маси тіла 3 гормональним статусом у жінок, хворих на гіпотиреоз автоімунного генезу (табл. 2), ми виявили позитивні кореляції середньої сили між рівнями ТТГ $(r=0,50)$, АТПО $(r=0,57)$, АТТГ $(r=0,35)$ та негативні кореляції середньої сили між рівнями в $_{4}(r=-0,37)$ і в $_{3}(r=-0,38)(p<0,05)$. Індекс маси тіла прямо корелював із ЗХС $(r=0,69), X С$ лПНЩ, КА $(r=0,65)$ і ТГ $(r=0,51)$ та виявляв зворотну кореляцію з ХС лПВЩ $(r=-0,36)(p<0,05)$. Перелічені вище взаємозв'язки спостерігали раніше. Результати, які ми отримали, збігаються 3 даними науковців, які підтверджують, що порушення ліпідного обміну є предиктором зростання індексу маси тіла, ожиріння та розвитку МС [11-13].

Дані літератури свідчать про те, що у пацієнтів з ГТ на тлі AІT частіше спостерігають ожиріння, більший об'єм талії і вищий індекс інсулінорезистентності HOMA-IR [14]. Зокрема, дослідники Yi Chen та ін. (2018) повідомили, що збільшений титр АТПО позитивно корелював 3 підвищеним індексом інсулінорезистентності HOMA-IR, центральним ожирінням, гіперліпідемією та МС, особливо в жінок [15].

Середній рівень глюкози в обстежуваних досягав $(5,49 \pm 0,06)$ ммоль/л, що відповідало референтним значенням. Рівень базального інсуліну перевищував контрольний показник у

Таблиця 1 - Кореляційні взаємозв'язки тиреотропного гормону, вільного тироксину, вільного трийодтироніну, антитіл до тиреопероксидази та антитіл до тиреоглобуліну з показниками ліпідограми в жінок пременопаузального віку, хворих на гіпотиреоз автоімунного генезу

\begin{tabular}{|c|c|c|c|c|c|}
\hline \multirow{2}{*}{ Показник } & \multicolumn{5}{|c|}{ Ступінь кореляції } \\
\hline & ТTГ & $\mathrm{BT}_{4}$ & $\mathrm{BT}_{3}$ & АТПО & ATTГ \\
\hline $3 \times C$ & $0,45^{\star}$ & $-0,31^{*}$ & $-0,28 *$ & $0,67 *$ & 0,30 * \\
\hline ХС ЛПНЩ & $0,40^{*}$ & $-0,27^{\star}$ & $-0,26^{\star}$ & $0,58^{\star}$ & $0,39 *$ \\
\hline ХС ЛПВЩ & $-0,14^{*}$ & $-0,01^{\star}$ & $0,06^{*}$ & $-0,34^{*}$ & $0,41^{*}$ \\
\hline ТГ & $0,13^{\star}$ & $0,04^{\star}$ & $-0,09 *$ & $0,48^{*}$ & $0,26^{\star}$ \\
\hline KA & $0,36^{\star}$ & $-0,18^{\star}$ & $-0,20 *$ & $0,60 *$ & $0,40^{\star}$ \\
\hline
\end{tabular}

Примітка. Тут і в таблицях 2, 3: * - достовірна відмінність між середніми значеннями $(p<0,05)$. 
Таблиця 2 - Кореляційні взаємозв'язки індексу маси тіла в жінок, хворих на гіпотиреоз автоімунного генезу

\begin{tabular}{|c|c|}
\hline Показник & Ступінь кореляції \\
\hline ТТГ & $0,50^{*}$ \\
\hline $\mathrm{BT}_{4}$ & $-0,37^{*}$ \\
\hline $\mathrm{BT}_{3}$ & $-0,38^{*}$ \\
\hline АТПО & $0,57^{*}$ \\
\hline ATTГ & $0,35^{\star}$ \\
\hline $3 \times C$ & $0,69^{*}$ \\
\hline ХС ЛПНЩ & $0,65^{*}$ \\
\hline ХС ЛПВЩ & $-0,36^{*}$ \\
\hline ТГ & $0,51^{*}$ \\
\hline KA & $0,65^{*}$ \\
\hline
\end{tabular}

79,4 \% пацієнток і в середньому становив $(28,63 \pm 0,88)$ мкОД/мл. Як маркер інсулінорезистентності при ГТ ми визначали індекс HOMA-IR та його кореляційні взаємозв'язки (табл. 3). Нам вдалося підтвердити спостереження авторів про позитивну кореляцію $(r=0,29)$ індексу інсулінорезистентності НОМА-IR з TTГ $[7,14]$. Виявлено позитивні кореляції середньої сили між індексом інсулінорезистентності й рівнем АТПО $(r=0,49)$ та негативні кореляції між рівнями в $\mathrm{T}_{4}(r=-0,22)$ і $\mathrm{BT}_{3}(\mathrm{r}=-0,31)(\mathrm{p}<0,05)$.

Таблиця 3 - Кореляційні взаємозв'язки індексу інсулінорезистентності HOMA-IR у жінок, хворих на гіпотиреоз автоімунного генезу

\begin{tabular}{|c|c|}
\hline Показник & Ступінь кореляції \\
\hline ТТГ & $0,29 *$ \\
\hline $\mathrm{BT}_{4}$ & $-0,22^{*}$ \\
\hline $\mathrm{BT}_{3}$ & $-0,31^{*}$ \\
\hline АТПО & $0,49 *$ \\
\hline ATTГ & $0,34^{\star}$ \\
\hline $3 \times C$ & $0,57^{*}$ \\
\hline ХС ЛПНЩ & $0,49 *$ \\
\hline ХС ЛПВЩ & $-0,13^{*}$ \\
\hline ТГ & $0,45^{\star}$ \\
\hline KA & $0,43^{*}$ \\
\hline
\end{tabular}

Крім відомих асоціацій індексу інсулінорезистентності HOMA-IR з інсуліном та глюкозою, виявлено прямі кореляції середньої сили між індексом HOMA-IR і 3XC $(r=0,57)$, KA $(r=0,43)$, ХС ЛПНЩ $(r=0,49)$, ТГ $(r=0,45)(p<0,05)$.

В обстежуваних жінок пременопаузального віку, хворих на ГТ на тлі АІT, спостерігали статистично значущі несприятливі порушення вуглеводного та ліпідного обміну, що визначає ступінь метаболічного і кардіоваскулярного ризику. Корекція метаболічного дисбалансу може сприяти профрілактиці та лікуванню ГТ, зумовленого AIT. Певні зміни, пов'язані з обміном речовин, такі, як поліпшення щоденного способу життя, контроль маси і корекція метаболічних дисбалансів, можуть сприяти профрілактиці та лікуванню AIT.

ВИСНОВКИ. 1. У жінок пременопаузального віку з гіпотиреозом на тлі автоімунного тиреоїдиту рівні тиреотропного гормону, антитіл до тиреопероксидази, антитіл до тиреоглобуліну і тиреоїдних гормонів асоціювалися 3 вуглеводноліпідними складовими протилежним чином. Виявлено прямий позитивний кореляційний взаємозв'язок середньої сили між рівнями тиреотропного гормону, антитіл до тиреопероксидази, антитіл до тиреоглобуліну та середній від'ємний кореляційний взаємозв'язок рівнів вільного тироксину і вільного трийодтироніну з показниками загального холестерину, холестерину ліпопротеїнів низької щільності та коефріцієнта атерогенності.

2. Достовірно позитивні кореляції середньої сили спостерігали між індексом маси тіла та рівнями тиреотропного гормону, антитіл до тиреопероксидази, антитіл до тиреоглобуліну, негативні кореляції середньої сили - 3 вільним тироксином і вільним трийодтироніном. Позитивний кореляційний взаємозв'язок встановлено між індексом маси тіла та рівнями загального холестерину, холестерину ліпопротеїнів низької щільності, тригліцеридів, коефіцієнтом атерогенності, середній від'ємний кореляційний зв'язок з холестерином ліпопротеїнів високої щільності.

3. Виявлено позитивні кореляції середньої сили між індексом інсулінорезистентності HOMA-IR та рівнями тиреотропного гормону, антитіл до тиреопероксидази, антитіл до тиреоглобуліну, негативні кореляції між рівнями вільного тироксину і вільного трийодтироніну. Встановлено прямі кореляції між індексом інсулінорезистентності HOMA-IR та рівнями загального холестерину, холестерину ліпопротеїнів низької щільності, тригліцеридів, коефіцієнтом атерогенності, негативні кореляції середньої сили - 3 холестерином ліпопротеїнів високої щільності.

4. Замісна гормональна терапія левотироксином натрію в жінок 3 гіпотиреозом на тлі автоімунного тиреоїдиту $є$ недостатньою для досягнення цільових рівнів основних показників метаболічного обміну.

Перспективи подальших досліджень. Подальші наукові дослідження будуть спрямовані на вивчення шляхів оптимізації профрілактики та лікування дисліпідемій і порушень вуглеводного обміну в жінок пременопаузального віку, хворих на гіпотиреоз автоімунного генезу. 


\section{СПИСОК ЛІТЕРАТУРИ}

1. Паньків В. І. Синдром гіпотиреозу / В. І. Паньків // Міжнар. ендокрин. журн. - 2012. - № 5 (45). - С. 136148.

2. Москва Х. А. Особливості кореляційних зв'язків показників інсулінорезистентності, вуглеводного та ліпідного обміну у хворих на гіпотиреоз / Х. А. Москва, Л. Є. Лаповець, О. П. Кіхтяк // Вісн. проблем біології і медицини. - 2013. - Вип. 3, 2 (103). - С. 211-216.

3. Laclaustra M. Impaired sensitivity to thyroid hormones is associated with diabetes and metabolic syndrome / M. Laclaustra, B. Moreno-Franco, J. M. LouBonafonte // Diabetes Care. - 2019. - 42 (2). - P. 303310. DOI:10.2337/dc18-1410.

4. Delitala A. P. Thyroid hormones, metabolic syndrome and its components / A. P. Delitala, G. Fanciulli, G. M. Pes // Endocr. Metab. Immune Disord. Drug Targets. - 2017. - 17 (1). - P. 56-62. DOI:10.2174/187 1530317666170320105221.

5. Iwen K. A. Metabolic syndrome in thyroid disease / K. A. Iwen, R. Oelkrug, H. Kalscheuer // Front Horm. Res. - 2018. - 49. - P. 48-66. DOI:10.1159/000485996.

6. Gu Y. The association between thyroid function and incidence of metabolic syndrome in euthyroid subjects: Tianjin chronic low-grade systemic inflammation and health cohort study / Y. Gu, Y. Wang, Q. Zhang // Clin. Endocrinol. (Oxf). - 2018. - 88 (5). - P. 735-743. DOI:10.1111/cen.13576.

7. Паньків В. І. Взаємозв'язок субклінічної дисфункції щитоподібної залози і метаболічного синдрому / В. І. Паньків, Т. Ю. Юзвенко // Клініч. ендокринологія та ендокрин. хірургія. - 2017. - № 2 (58). C. $39-43$

8. Alessandro P. Delitala. Thyroid hormones, metabolic syndrome and its components / Alessandro P. Delitala, Giuseppe Fanciulli, Giovanni M. Pes // Endocrine, Metabolic \& Immune Disorders - Drug Targets. - 2017.

\section{REFERENCES}

1. Pankiv, V.I. (2012). Syndrom hipotyreozu [Hypothyroidism syndrome]. Mizhnarodnyi endokrynolohichny zhurnal - International Journal of Endocrinology, 5 (45) [in Ukrainian].

2. Moskva, Kh.A., Lapovets, L.le., \& Kikhtiak, O.P. (2013). Osoblyvosti koreliatsiinykh zviazkiv pokaznykiv insulinorezystentnosti, vuhlevodnoho ta lipidnoho obminu u khvorykh na hipotyreoz [Peculiarities of correlations of indicators of insulin resistance, carbohydrate and lipid metabolism in patients with hypothyroidism]. Visnyk problem biolohii i medytsyny - Bulletin of Problems of Biology and Medicine, 3 (103), 211 [in Ukrainian].

3. Laclaustra, M., Moreno-Franco B., \& Lou-Bonafonte, J.M. (2019). Impaired sensitivity to thyroid hormones is associated with diabetes and metabolic syndrome. Diabetes Care, 42 (2), 303-310.

4. Delitala, A.P., Fanciulli, G. \& Pes, G.M. (2017). Thyroid hormones, metabolic syndrome and its components. Endocr. Metab. Immune Disord. Drug Targets, 17 (1), 56-62.

5. Iwen, K.A., Oelkrug, R. \& Kalscheuer, H. (2018). Metabolic syndrome in thyroid disease. Front. Horm. Res., 49, 48-66.
- 17. - P. 56 - 62. DOI: 10.2174/187153031766617032 0105221.

9. Wu Y. The correlation between metabolic disorders and TPOAB/TGAB: a cross-sectional population-based study / Y. Wu, X. Shi, X. Tang // Endocr. Pract. - 2020. 26 (8). - P. 869-882. DOI:10.4158/EP-2020-0008.

10. Raposo L. Metabolic syndrome, thyroid function and autoimmunity - the PORMETS study / L. Raposo, S. Martins, D. Ferreira // Endocr. Metab. Immune Disord. Drug Targets. - 2019. - 19 (1). - P. 75-83. DOI:10.217 $4 / 1871530318666180801125258$.

11. Hertelyova $Z$. The association between lipid parameters and obesity in university students / Z. Hertelyova, R. Salaj, A. Chmelarova // J. Endocrinol. Invest. 2016. - 39 (7). - P. 769-778. DOI:10.1007/s40618-0150240-8.

12. Taghizadeh S. The role of lipids in the pathogenesis of metabolic syndrome in adolescents / S. Taghizadeh, M. Alizadeh // Exp. Clin. Endocrinol. Diabetes. - 2018.126 (1). - P. 14-22. DOI:10.1055/s-0043-106439.

13. Mehran L. Thyroid function and metabolic syndrome: A population-based thyroid study / L. Mehran, A. Amouzegar, P. K. Rahimabad // Horm. Metab. Res. 2017. -49 (3). - P. 192-200. DOI:10.1055/s-0042-117279.

14. Siemińska L. Associations between metabolic syndrome, serum thyrotropin, and thyroid antibodies status in postmenopausal women, and the role of interleukin-6 / L. Siemińska, C. Wojciechowska, K. Walczak // Endokrynol. Pol. - 2015. - 66 (5). - P. 394-403. DOI:10.5603/EP.2015.0049.

15. Chen Yi. Are thyroid autoimmune diseases associated with cardiometabolic risks in a population with normal thyroid-stimulating hormone? / Yi. Chen, C. Zhu, Y. Chen // Mediators Inflamm. - 2018. - ID 1856137. DOI:10.1155/2018/1856137.

6. Gu, Y., Wang, Y. \& Zhang Q. (2018). The association between thyroid function and incidence of metabolic syndrome in euthyroid subjects: Tianjin chronic low-grade systemic inflammation and health cohort study. Clin. Endocrinol. (Oxf.), 88 (5),735-743.

7. Pankiv, V.I., \& Yuzvenko T.lu. (2017). Vzaiemozviazok subklinichnoi dysfunktsii shchytopodibnoi zalozy i metabolichnoho syndromu [Relationship between subclinical thyroid dysfunction and metabolic syndrome]. Klinichna endokrynolohiia ta endokrynna khirurhiia - Clinical Endocrinology and Endocrine Surgery, 2 (58), 39-43.

8. Alessandro, P.D., Fanciulli, G. \& Pes, G. (2017). Thyroid hormones, metabolic syndrome and its components. Endocrine, Metabolic \& Immune Disorders Drug Targets, 17, 56-62.

9. Wu, Y., Shi, X. \& Tang X. (2020). The correlation between metabolic disorders and TPOAB/TGAB: a crosssectional population-based study. Endocr. Pract., 26 (8), 869-882.

10. Raposo, L., Martins, S. \& Ferreira, D. (2019). Metabolic syndrome, thyroid function and autoimmunity the PORMETS study. Endocr. Metab. Immune Disord. Drug Targets, 19 (1), 75-83. 
11. Hertelyova, Z., Salaj R. \& Chmelarova A. (2016). The association between lipid parameters and obesity in university students. J. Endocrinol. Invest, 39(7), 769-778.

12. Taghizadeh, S., \& Alizadeh, M. (2018). The role of lipids in the pathogenesis of metabolic syndrome in adolescents. Exp. Clin. Endocrinol. Diabetes, 49 (3), 192-200.

13. Mehran, L., Amouzegar, A. \& Rahimabad, P.K. (2017). Thyroid function and metabolic syndrome: A population-based thyroid study. Horm. Metab. Res., 49 (3), 192-200.
14. Siemińska, L., Wojciechowska, C. \& Walczak, K. (2015). Associations between metabolic syndrome, serum thyrotropin, and thyroid antibodies status in postmenopausal women, and the role of interleukin-6. Endokrynol. Pol., 66 (5), 394-403.

15. Chen, Y., Zhu, C. \& Chen, Y. (2018). Are thyroid autoimmune diseases associated with cardiometabolic risks in a population with normal thyroid-stimulating hormone? Mediators Inflamm., ID 1856137.

\section{ОСОБЕННОСТИ УГЛЕВОДНОГО И ЛИПИДНОГО ОБМЕНА У ЖЕНЩИН ПРЕМЕНОПАУЗАЛЬНОГО ВОЗРАСТА С ГИПОТИРЕОЗОМ АУТОИММУННОГО ГEHE3A}

\section{Резюме}

Вступление. Дисфункцию щитовидной железы считают распространенным эндокринным заболеванием, в структуре которого преобладает гипотиреоз. В большинстве случаев гипотиреоз является следствием аутоиммунного тиреоидита, который чаще встречается у женщин. Рост уровня тиреотропного гормона коррелирует с параметрами метаболического синдрома, увеличивает сердечно-сосудистые события и общую смертность.

Цель исследования - изучить особенности корреляционных взаимосвязей тиреотропного гормона, тиреоидных гормонов и антител к тиреопероксидазе с углеводно-липидными показателями у женщин пременопаузального возраста, больных гипотиреозом аутоиммунного генеза.

Методы исследования. Обследовано 146 женщин пременопаузального возраста с гипотиреозом аутоиммунного генеза. Всем пациенткам проводили антропометрические, общеклинические, биохимические обследования, включая определение углеводного и липидного обмена, оценивали фрункциональное состояние их щитовидной железы, определяя уровень тиреотропного гормона, свободного тироксина, свободного трийодтиронина и антител к тиреопероксидазе. Результаты исследований анализировали методом вариационной статистики с помощью программы STATISTICA 12 (“Statsoft”, CШA).

Результаты и обсуждение. Уровни тиреотропного гормона, антител к тиреопероксидазе характеризовались прямой корреляционной взаимосвязью средней силы с общим холестерином, триглицеридами, липопротеинами низкой плотности, коэффрициентом атерогенности, а уровни свободного тироксина и свободного трийодтиронина - обратной связью. Установлено достоверно положительные корреляции средней силы индекса массы тела и индекса инсулинорезистентности HOMA-IR с тиреотропным гормоном, антителами к тиреопероксидазе и отрицательные корреляции средней силы со свободным тироксином и свободным трийодтиронином. Выявлено положительную корреляционную взаимосвязь индекса массы тела и индекса инсулинорезистентности HOMA-IR с уровнями общего холестерина, холестерина липопротеинов низкой плотности, триглицеридов, коэфффициентом атерогенности и отрицательную корреляционную взаимосвязь с холестерином липопротеинов высокой плотности.

Вывод. Исследование корреляционных взаимосвязей углеводного и липидного обмена у женщин пременопаузального возраста, больных гипотиреозом аутоиммунного генеза, является актуальным и перспективным направлением для изучения механизмов развития метаболического синдрома и его коррекции. Заместительная гормональная терапия левотироксином натрия у женщин с гипотиреозом аутоиммунного генеза недостаточная для достижения целевых уровней основных показателей метаболического обмена.

КЛЮЧЕВЫЕ СЛОВА: аутоиммунный тиреоидит; гипотиреоз; женщины; пременопаузальный возраст; корреляции; дислипидемия; инсулинорезистентность. 


\section{PECULIARITIES OF CARBOHYDRATE AND LIPID METABOLISM IN PREMENOPAUSAL WOMEN WITH AUTOIMMUNE HYPOTHYROIDISM}

\section{Summary}

Introduction. Thyroid dysfunction (TD) is considered as a common endocrine disease in the structure of which prevails hypothyroidism (HT). In most cases, HT is a consequence of autoimmune thyroiditis (AIT), which is most common in women. The increase of thyroid-stimulating hormone correlates with the parameters of the metabolic syndrome, which increases cardiovascular events and mortality.

The aim of the study - to investigate the correlations between thyroid-stimulating hormone (TSH), thyroid hormones and antibodies to thyroperoxidase (ATPO) with carbohydrate-lipid parameters in premenopausal women with autoimmune hypothyroidism.

Research Methods. 146 premenopausal women with HT were examined. All women underwent anthropometric, general clinical, biochemical examinations, including determination of lipid metabolism, hydrocarbon metabolism and assessed the functional status of the thyroid gland by determining the level of TSH, free thyroxine (BT4), free triiodothyronine (BT3) and ATPO. The results of the research were analyzed by the method of variation statistics using the program STATISTICA 12 ("Statsoft", USA).

Results and Discussion. We found that the level of TSH and ATPO were characterized by a direct correlation of moderate strength with total cholesterol, triglycerides, low-density lipoprotein, atherogenic factor. We found that TSH and ATPO levels were characterized by a direct correlation of moderate strength with total cholesterol, triglycerides, low-density lipoprotein, atherogenic factor, and fT4 and fT3 were characterized by an inverse relationship. Were established significantly positive correlations of the mean strength of body mass index and HOMA-IR insulin resistance index with TSH and ATPO and negative correlations of average force with $\mathrm{fT} 4$ and fT3. A positive correlation was found between body mass index and HOMA-IR insulin resistance index with levels of total cholesterol, lowdensity lipoprotein cholesterol, triglycerides, atherogenic factor, and a negative correlation with high-lipoprotein cholesterol.

Conclusion. The study of correlations between carbohydrate and lipid metabolism in premenopausal women with autoimmune hypothyroidism is a relevant and promising area for studying the mechanisms of development of metabolic syndrome and its correction. Hormone replacement therapy with levothyroxine sodium in women with autoimmune hypothyroidism is insufficient to achieve the target levels of basic metabolic parameters.

KEY WORDS: autoimmune thyroiditis; hypothyroidism; women; premenopausal age; correlations; dyslipidemia; insulin resistance.

Адреса для листування: О. О. Чукур, Тернопільський національний медичний університет імені І. Я. Горбачевського МОЗ України, майдан Волі, 1, Тернопіль, 46001, Україна, e-mail: chukur@tdmu.edu.ua. 